\title{
Mechanical and Microstructural Characterization of AS-CAST Ti-12Mo-xNb Alloys for Orthopedic Application
}

\author{
Caio Marcello Felbinger Azevedo Cossúa, ${ }^{a *} \mathbb{D}^{-}$Edson Dornas Vicente ${ }^{a}$, Italo Gomes Raulino Cardoso ${ }^{a}$, \\ Yuri Salum Schettini ${ }^{a}$, João de Ataíde Garcia Precioso ${ }^{a}$, Carlos Angelo Nunesc, Luiz Henrique de \\ Almeida $^{b}$, Sinara Borborema ${ }^{a}$ \\ ${ }^{a}$ Universidade do Estado do Rio de Janeiro, Faculdade de Tecnologia de Resende, Departamento de \\ Engenharia Mecânica, 27533-000, Resende, RJ, Brasil \\ ${ }^{b}$ Universidade Federal do Rio de Janeiro, Departamento de Engenharia Metalúrgica e de Materiais, \\ C.P. 68505, 21945-970, Rio de Janeiro, RJ, Brasil \\ ${ }^{c}$ Universidade de São Paulo, Escola de Engenharia de Lorena, Departamento de Engenharia de \\ Materiais, Pólo Urbo-Industrial, Gleba AI-6, s/no , 12.600-970, Lorena, SP, Brasil
}

Received: February 25, 2019; Revised: September 05, 2019; Accepted: December 04, 2019

The development of $\beta$-metastable titanium alloys that combine low Young's modulus, good mechanical properties, corrosion resistance and biocompatibility has attracted industry interest. This type of alloy is an alternative to commercial alloys such as Ti-6Al-4V, avoiding the cytotoxic effect that occurs with $\mathrm{Al}$ and $\mathrm{V}$ in the human body in the manufactured orthopedic prostheses. In this scenario, the present work aims to characterize the effect of $\mathrm{Nb}$ concentration in the properties of Ti alloys based on the Ti-12Mo-xNb stoichiometry $(\mathrm{x}=0,3,8,13,17$ and 20). All alloys were produced by arc melting with non-consumable tungsten electrode in an argon atmosphere and the ingots were characterized by x-ray diffraction (XRD), optical microscopy (OM), Vickers microhardness and Young's modulus was measured by impulse excitation and density was measured using the Archimedes' principle. The Ti-12Mo alloy and the Ti-12Mo-20Nb alloy showed the lowest Young's modulus. The best hardness/ modulus was found for the Ti-12Mo-3 Nb alloy. All the alloys studied in this work showed hardness/ modulus ratio above the traditional Ti-6Al- $4 \mathrm{~V}$ alloy $(2.85)$, presented great potential for the biomedical application.

Keywords: Biomaterials, Ti-Mo-Nb alloys, microstructure, mechanical properties.

\section{Introduction}

Stainless steels, Co-Cr and titanium alloys are largely used as biomedical implants because of their good mechanical properties and excellent corrosion resistance. However, studies have shown that implants made of stainless steel or Co-Cr alloy increased the risk of cancer cells developing in the body over time due to the presence of cytotoxic elements ${ }^{1}$ and, besides that, the Young's modulus of the titanium alloys is much lower than that of the stainless steels (200 GPa) and Co-Cr alloys (200-230 GPa) ${ }^{2}$.

The development of titanium alloys for biomedical application has been of great interest because they combine excellent mechanical properties such as low Young's modulus, high tensile strength, fatigue resistance, good ductility and excellent corrosion resistance to body fluids. Currently, the most commonly titanium alloy used for biomedical application is the Ti-6Al-4V $(110 \mathrm{GPa})^{2-5}$. However, studies have indicated that the release of aluminum ions causes neurological problems related to Alzheimer's disease and the release of vanadium ions causes cellular problems, and later cell death ${ }^{6-8}$. In order to replace these toxic elements, some alternatives such as the addition of $\mathrm{Cu}, \mathrm{Mn}, \mathrm{Nb}, \mathrm{Sn}$, $\mathrm{Fe}, \mathrm{Ta}, \mathrm{Zr}$ and Mo have been developed maintaining the

*e-mail: caio.cossu@usp.br combination between high mechanical strength, low Young's modulus and corrosion resistance in these new materials ${ }^{9-11}$.

The low Young's modulus is required in these alloys to minimize the difference between the implant modulus and the adjacent bone tissue modulus (30-40 GPa). It is known that the difference between the Young's modulus of the implant and human bone causes a "stress shielding effect" due to a problem of stiffness incompatibility. This phenomenon occurs when the implant absorbs a large part of the applied load leaving the bony tissues without stress. The effects of this undesired absorption lead to loss of bone density (osteoporosis), and consequently to atrophy of the bone tissues by disuse around the implant site, loosening and leading to an eventual premature failure of the implant ${ }^{5,12}$.

According to Xu et al. ${ }^{5}$ Ti-Mo alloys have been extensively studied as $\beta$ titanium alloys for biomedical applications. The Young's modulus of Ti-Mo alloys (60-80 GPa) is lower than that of other alloys for implant production. Borborema et al. ${ }^{13}$ studied the Ti-10Mo-xNb system and found that alloys containing less than $9 \mathrm{wt} . \%$ niobium had $\alpha+\beta$ microstructure. Alloys containing contents above $9 \%$ by weight of niobium presented single $\beta$ phase microstructure. According to Borborema et al. ${ }^{13}$ the increase in phase $\beta$ volumetric fraction causes the decrease hardness.

Therefore, the objective of this work was to analyze the as-cast Ti-12Mo-xNb alloys system observing the 
influence of the addition of niobium on mechanical properties, such as hardness and Young's modulus, of $\beta$-metastable (10-30wt.\% Mo) titanium alloys, providing a new alternative for the Ti-6Al-4V alloy currently used for biomedical applications.

\section{Materials and Methods}

The Ti-12Mo-xNb ingots $(\mathrm{x}=0,3,8,13,17$ and 20) were produced from high purity metal sheets: commercially pure (CP) Ti (grade 2 according to ASTM F6706, supplied by EEL/USP, Brazil), Nb (>99.999\% purity, supplied by EEL/USP, Brazil) and Mo ( $>99.9 \%$ purity, supplied by Plansee Group ${ }^{\circledR}$, Austria). The thin sheets containing the materials were cut into small pieces and chemically pickled for removal of surface impurities.

The initial mass for the production of the ingots was $40 \mathrm{~g}$. The ingots were melted by arc fusion with nonconsumable tungsten electrode in an inert argon atmosphere in a water-cooled crucible with $50 \mathrm{~mm}$ length. To ensure chemical homogeneity, the ingots were remelted five times and cooled inside the furnace. The density of the alloys was measured according to ASTM C20-00 ${ }^{14}$ based on the Arquimedes principle.

Microstructural characterization was on the polished surface using a PANalytical ${ }^{\circledR}$ Empyrean diffractometer operating at $40 \mathrm{kV}$ and $30 \mathrm{~mA}$ with $\mathrm{Cu}-\mathrm{K} \alpha$ radiation $(\lambda=1.5418 \AA)$, scanning a $2 \Theta$ range from $20^{\circ}$ to $90^{\circ}$, with a step size of $0.02^{\circ}$. The crystalline phases were identified through the comparison of the obtained data with simulated diffractograms using PHILIPS ${ }^{\circledR}$ X'Pert HighScore 3.0 software with the PDF4-ICDD database based on the JCPDS microfiche ${ }^{15}$. Samples were observed by OM to show the morphology of the grains. All samples for OM were cold mounted in resin, ground $\mathrm{SiC}$ papers up to $4000 \mathrm{mesh}$, polished in a suspension composed by $260 \mathrm{~mL} \mathrm{OP-S,} 40 \mathrm{~mL} \mathrm{H}_{2} \mathrm{O}_{2}, 1 \mathrm{~mL} \mathrm{HNO}_{3}$ and $0.50 \mathrm{~mL} \mathrm{HF}$ then etched with Kroll's reagent $\left(6 \mathrm{~mL} \mathrm{HNO}_{3}\right.$, $3 \mathrm{~mL} \mathrm{HF}$ and $100 \mathrm{~mL} \mathrm{H}_{2} \mathrm{O}$ ) to reveal grain boundaries ${ }^{16}$. The samples were etched for 30 to $180 \mathrm{~s}$.

The hardness of the alloys was measured using a durometer BUEHLER ${ }^{\circledR}$ Micromet 6020 tester with a load of $100 \mathrm{gf}(0.981 \mathrm{~N})$ for $30 \mathrm{~s}$ in accordance ASTM E92 ${ }^{17}$ and ASTM E384 ${ }^{18}$. The hardness values were based on the average of ten measurements. The Young's modulus of the as-cast Ti-12Mo-xNb alloys was obtained using an ATCP ${ }^{\circledR}$ Sonelastic impulse excitation equipment. According to ASTM E1876 - $09^{19}$, the surface of samples dimensions was 10 $\mathrm{mm}$ in diameter and $0.60 \mathrm{~mm}$ in thickness.

The value of the Young's modulus of the alloys was determined by the average of eight measurements. The comparison of values of Vickers microhardness and Young's modulus of as-cast Ti-12Mo-xNb alloys with CP Ti and Ti-6Al-4V alloy was performed under the same condition.

\section{Results and Discussion}

After melting the ingots, the mass variation was less than $1 \%$. The as-cast $\mathrm{Ti}-12 \mathrm{Mo}-\mathrm{xNb}$ alloys showed values $\mathrm{Mo}_{\mathrm{eq}}$ greater than $12 \mathrm{wt} . \%$ as indicated in Table 1 . The densities of the alloys increase according to the niobium content, because the density of niobium $\left(\rho=8.57 \mathrm{~g} / \mathrm{cm}^{3}\right)$ is about twice as high as that of titanium $\left(\rho=4.51 \mathrm{~g} / \mathrm{cm}^{3}\right)$.

Table 1. Density and mass composition of alloys in molybdenum equivalence (Moeq.)

\begin{tabular}{lcc}
\hline Materials & Moeq. [wt.\%] & Density $\left[\mathbf{g} / \mathbf{c m}^{3}\right]$ \\
\hline CP Ti & - & $4.50^{17}$ \\
Ti-6Al-4V & - & $4.46^{17}$ \\
Ti-12Mo & 12.00 & 4.92 \\
Ti-12Mo-3Nb & 12.84 & 5.02 \\
Ti-12Mo-8Nb & 14.24 & 5.10 \\
Ti-12Mo-13Nb & 15.64 & 5.22 \\
Ti-12Mo-17Nb & 16.76 & 5.29 \\
Ti-12Mo-20Nb & 17.60 & 5.46 \\
\hline
\end{tabular}

The XRD patterns shown in Figure 1 indicate the presence of single $\beta$ phase in as-cast Ti-12Mo-xNb alloys in agreement with the pseudo-binary molybdenum equivalence diagram $\left(\mathrm{Mo}_{\text {eq }}\right)$ proposed by Cotton et al. ${ }^{20}$ and observations made by Ho et al. ${ }^{21}$ and $\mathrm{Xu}$ et al. ${ }^{22}$ which show that, for contents above $10 \mathrm{wt} . \% \mathrm{Mo}_{\text {eq. }}$, titanium alloys are classified as $\beta$-metastable.

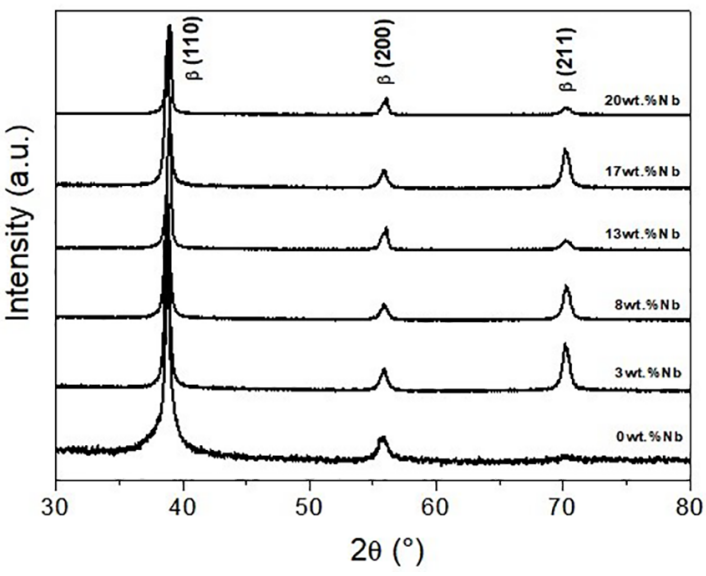

Figure 1. XRD of the as-cast Ti-12Mo-xNb alloys

Figure 2 shows different OM of the as-cast Ti-12Mo$\mathrm{xNb}$ alloys. The micrographs showed the presence of single $\beta$ phase matrix and the formation of dendrites in the grains due to the lack of homogenization of the chemical elements that make up the alloys caused by the secondary solidification process, being one of the characteristics of the as-cast alloys ${ }^{23}$. Moreover, it was observed that the niobium addition carried in refined dendrites. 


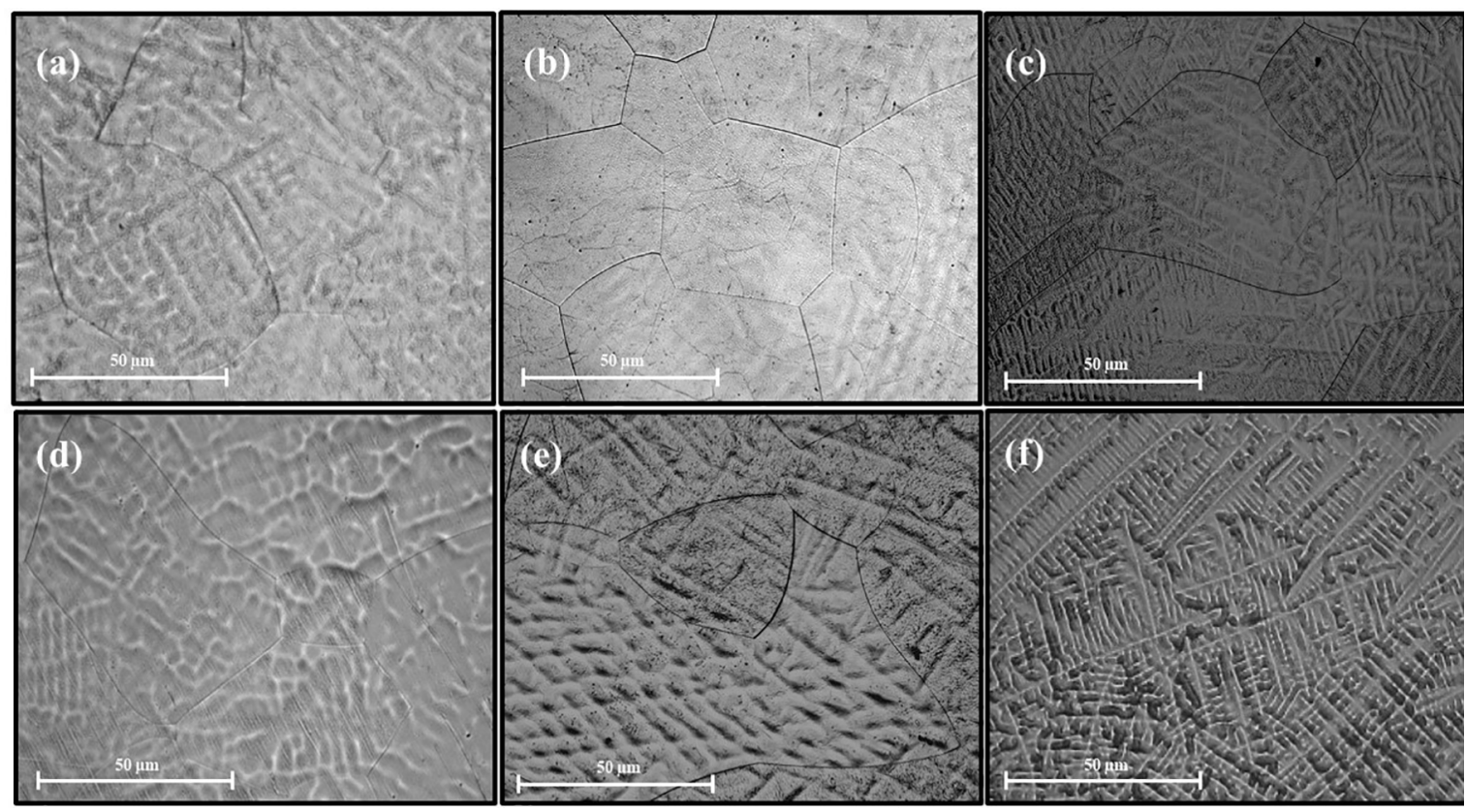

Figure 2. OM of the as-cast Ti-12Mo-xNb alloys: (a) $\mathrm{x}=0$; (b) $\mathrm{x}=3 \%$; (c) $\mathrm{x}=8 \%$; (d) $\mathrm{x}=13 \%$; (e) $\mathrm{x}=17 \%$ e (f) $\mathrm{x}=20 \%$

Figure 3 shows the hardness values in function of the increase of niobium addition in the as-cast Ti- $12 \mathrm{Mo}-\mathrm{xNb}$ alloys. The hardness of as-cast Ti-12Mo-xNb was influenced by addition niobium. According with the technique used in the work, the alloys showed single $\beta$ phase in the microstructure. Experimental observations showed that increasing niobium concentration in the Ti-Mo system with $\beta$ matrix, decreases hardness as also reported by Zhang et al. ${ }^{24}$. In this case, niobium reduces the lattice parameter and affects the relationship $\frac{c}{a}$.

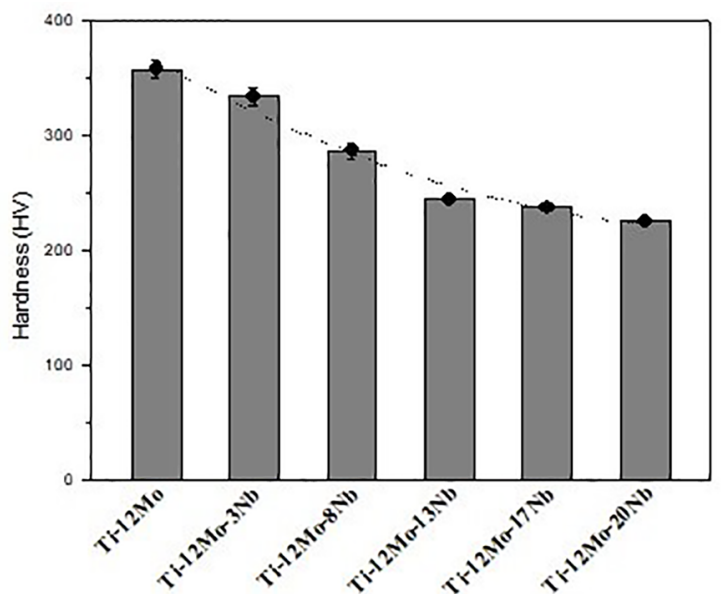

Figure 3. Variation of hardness in according with increase the niobium content in the as-cast $\mathrm{Ti}-12 \mathrm{Mo}-\mathrm{xNb}$ alloys.

The same effect was corroborated by Borborema et al. ${ }^{13,23,25}$ and Kin et al. ${ }^{26}$ reporting that niobium acts as a $\beta$-stabilizer and in controlled cooling other phases are not formed (eg $\omega$ phase) and hardness decreases as a result of increasing niobium content.
The Vickers hardness values of the as-cast Ti-12Mo-xNb alloys (226-358 HV) were higher than that of CP Ti (199 $\mathrm{HV})$. The Ti-12Mo and Ti-12Mo-3 $\mathrm{Nb}$ alloys presented higher hardness values than that of as-cast Ti-6Al-4V alloy (294HV).

Figure 4 shows the values of the Young's modulus for the alloys as a function of the increase of niobium in the as-cast Ti-12Mo-xNb alloys.

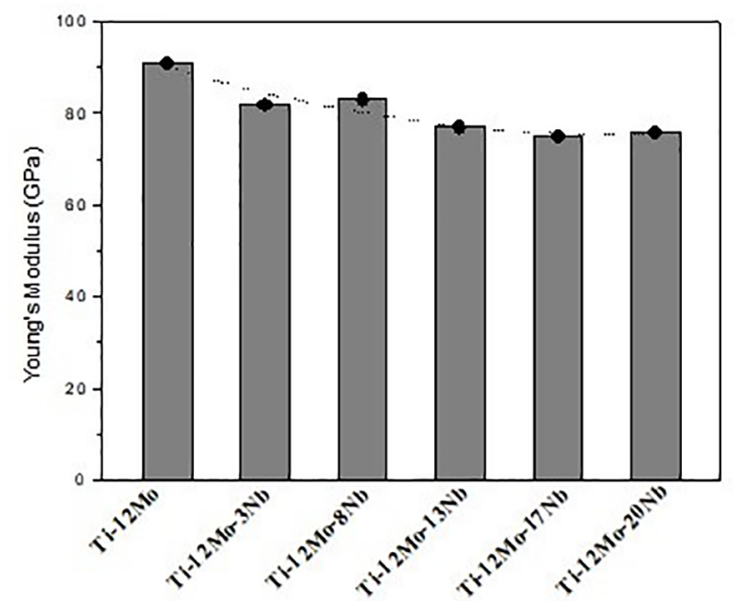

Figure 4. Variation of Young's modulus in according with increase the niobium content in the as-cast Ti-12Mo-xNb alloys.

Nnamchi et al. 28 studied the effects of increase the niobium in binary alloys of the Ti-Mo-Nb-Zr system. Alloys contained $14 \mathrm{wt} . \%$ and $40 \mathrm{wt} . \%$ of niobium were arc melted and cooled inside the furnace. The results obtained indicated that produced alloys showed single $\beta$ phase and Young's modulus decrease: 14wt.\% (95 GPa) and $40 \mathrm{wt} . \%(90 \mathrm{GPa})$. 
Dercza et al. ${ }^{29}$ obtained a Young's modulus value of $67 \mathrm{GPa}$ for the single $\beta$ phase in the Ti-70Ta alloy $\left(\mathrm{Mo}_{\text {eq. }}=15.4 \mathrm{wt} . \%\right)$. $\mathrm{Xu}$ et al. ${ }^{5,22}$ reported that the Young's modulus of the Ti12Mo alloy produced using the Metal Injection Moulding (MIM) technique was $73 \pm 5 \mathrm{GPa}$.

The Young's modulus values of the as-cast Ti-12Mo-xNb alloys (76-91 GPa) were lower than those CP Ti (103 GPa) and the traditional Ti-6Al-4V alloy (118 GPa). Therefore, the Young's modulus of the system studied was between 23 to $36 \%$ lower than that of Ti-6Al-4V alloy. The Ti-12Mo alloy in this study presented higher Young's modulus ( $86 \mathrm{GPa})$ and the addition of niobium resulted in the decrease of the modulus reaching the lowest value in the Ti-12Mo-20Nb alloy (76 GPa).

It is known that Young's modulus and hardness vary in the same proportion by niobium addition to titanium alloys. Due to this characteristic its necessary to find the best relation between these two properties. For this reason, the hardness/ modulus ratio is often used to evaluate the mechanical performance of metallic biomaterials for implants ${ }^{29}$.

In Figure 5 is shown a comparison of hardness/ modulus ratio among as-cast Ti-12Mo-xNb alloys, $\mathrm{CP}$ $\mathrm{Ti}$ and Ti-6Al-4V alloy. The results of the experimentally measured standards for Ti $\mathrm{CP}$ had a hardness/modulus ratio of 1.99 and Ti-6Al-4V alloy had a ratio of 2.85 . All the as-cast Ti-12Mo-xNb alloys alloys studied in this work had a higher hardness/modulus ratio than the traditional Ti-6Al-4V alloy and CP Ti, thus presenting great potential for biomedical application, with emphasis on the binary Ti-12Mo alloy and as-cast Ti-12Mo-3Nb alloy with the highest hardness/modulus ratios (4.08 and 4.12 , respectively).

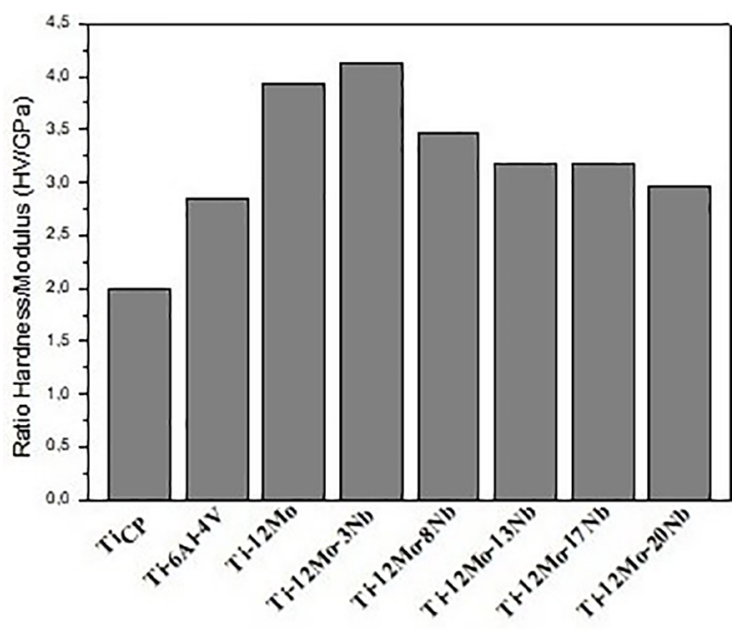

Figure 5. Hardness/modulus ratio for CP Ti, Ti-6Al-4V alloy and as-cast $\mathrm{Ti}-12 \mathrm{Mo}-\mathrm{xNb}$ alloys

\section{Conclusion}

All the produced alloys in the as-cast condition present a single $\beta$ phase microstructure. The increase in the niobium content promoted a decrease in hardness and Young's modulus.
The highest hardness was found for $\mathrm{x}=0(355 \mathrm{HV})$ and the addition of niobium reduced the hardness of the alloy to $x=20$. The lowest value of the Young's modulus was observed in $\mathrm{x}=20(76 \mathrm{GPa})$.

The better combination of mechanical properties (hardness/modulus ratio) was observed for $\mathrm{x}=3$ (4.12), presenting superior results to the Ti-6Al-4V alloy (2.85) and CP Ti (1.99).

Finally, all the alloys had hardness/modulus ratios higher than those Ti-6Al-4V alloy and CP Ti, showing a great potential for orthopedic application.

\section{Acknowledgements}

This work was supported by brazilian agencies $\mathrm{CNPq}$, FAPERJ and CAPES.

\section{References}

1. Chapala P, Kumar PS, Joardar J, Bhandari V, Acharyya SG. Effect of alloying elements on the microstructure, coefficient of friction, in-vitro corrosion and antibacterial nature of selected Ti-Nb alloys. Applied Surface Science. 2019;469:617-623.

2. Xu JL, Tao SC, Bao LZ, Luo JM, Zheng YF. Effects of Mo contents on the microstructure, properties and cytocompatibility of the microwave sintered porous Ti-Mo alloys. Materials Science \& Engineering: C. 2019;97:156-165.

3. Zhou YL, Niinomi M, Akahori T, Fukui H, Toda H. Corrosion resistance and biocompatibility of Ti-Ta alloys for biomedical applications. Materials Science and Engineering: A. 2005;398(1-2):28-36.

4. Gunawarman B, Niinomi M, Akahori T, Takeda J, Toda H. Mechanical properties of $\mathrm{Ti}-4.5 \mathrm{Al}-3 \mathrm{~V}-2 \mathrm{Mo}-2 \mathrm{Fe}$ and possibility for healthcare applications. Materials Science and Engineering: C. $2005 ; 25(3): 296-303$.

5. Zhoua YL, Niinomi M. Microstructures and mechanical properties of Ti-50 mass\% Ta alloy for biomedical applications. Journal of Alloys and Compounds. 2008;466(1-2):535-542.

6. Mohammed MT, Khan ZA, Geetha M, Siddiquee AN. Microstructure, mechanical properties and electrochemical behavior of a novel biomedical titanium alloy subjected to thermo-mechanical processing including aging. Journal of Alloys and Compounds. 2015;634:272-280.

7. Xu LJ, Chen YY, Liu ZG, Kong FT. The microstructure and properties of Ti-Mo-Nb alloys for biomedical application. Journal of Alloys and Compounds. 2008;453(1-2):320-324.

8. Einsenbarth E, Velten D, Müller M, Thull R, Breme J. Biocompatibility of beta-stabilizing elements of titanium alloys. Biomaterials. 2004;25(26):5705-5713.

9. Kuroda D, Kawasaki H, Yamamoto A, Hiromoto S, Hanawa T. Mechanical properties and microstructures of new Ti-Fe-Ta and Ti-Fe-Ta-Zr system alloys. Materials Science and Engineering: C. $2005 ; 25(3): 312-320$.

10. Banerjee R, Nag S, Fraser HL. A novel combinatorial approach to the development of beta titanium alloys for orthopaedic implants. Materials Science and Engineering: C. $2005 ; 25(3): 282-289$. 
11. Xu W, Kim KB, Das J, Calin M, Eckert J. Phase stability its effect on the deformation behavior of Ti-Nb-Ta-In/ $\mathrm{Cr} \beta$ alloys. Scripta Materialia. 2006;54(11):1943-1948.

12. Li Y, Yang C, Zhao H, Qu S, Li X, Li YY. New developments of Ti-based alloys for biomedical applications. Materials (Basel). 2014;7(3):1709-1800.

13. Gabriel BS, Nunes CA, Soares GA. Production, microstructural characterization and mechanical propertier of as-cast Ti-10MoxNb alloys. Artificial Organs. 2008;32(4):299-304.

14. American Society for Testing Materials (ASTM). C20-00 Standard test methods for apparent porosity, water absorption, apparent specific gravity, and bulk density of burned refractory brick and shapes by boiling water. West Conshohocken, PA: ASTM International; 2015.

15. Joint Committee on Powder Diffraction Standard (JCPDS). International Centre for Diffraction Data. Swarthmore, PA: JCPDS; 2004.

16. American Society for Testing Materials (ASTM). E407-07 Standard practice for microetching metals and alloys. West Conshohocken, PA: ASTM International; 2015.

17. American Society for Testing Materials (ASTM). E92 - 17 - Standard test methods for Vickers hardness and Knoop hardness of materials metallics. West Conshohocken, PA: ASTM International; 2017.

18. American Society for Testing Materials (ASTM). E384 - 17 Standard test method for microindentation hardness of materials. West Conshohocken, PA: ASTM International; 2017.

19. American Society for Testing Materials (ASTM). E1876 - 09 - Standard test method for dynamic Young's modulus, shear modulus, and Poisson's ratio by impulse excitation of vibration. West Conshohocken, PA: ASTM International; 2017.

20. Cotton JD, Briggs RD, Boyer RR, Tamirisakandala S, Russo $\mathrm{P}$, Shchennikov N, et al. State of the art in beta titanium alloys for airframe applications. The Journal of the Minerals, Metals \& Materials Society. 2015;67(6):1281-1303.
21. Ho WF, Ju CP, Lin JHC. Structure and properties of cast binary Ti-Mo alloys. Biomaterials. 1999;20:2115-2122.

22. Xu W, Lu X, Wang LN, Shi ZM, Lv SM, Qian M, et al. Mechanical properties, in vitro corrosion resistance and biocompatibility of metal injection molded Ti-12Mo alloy for dental applications. Journal of the Mechanical Behavior of Biomedical Materials. 2018;88:534-547.

23. Borborema S, Almeida LH, Nunes CA, Dille J, Soares GA. Maximisation of the ratio of microhardness to the Young's modulus of Ti-12Mo-13Nb alloy through microestructure changes. Materials Science and Engineering: C. 2013;33(6):3319-24.

24. Zhang LB, Wang KZ, Xu LJ, Xiao SL, Chen YY. Effect of $\mathrm{Nb}$ addition on microstructure, mechanical properties and castability of $\beta$-type Ti-Mo alloys. Transactions Nonferrous Metals Society of China. 2015;25(7):2214-2220.

25. Gabriel SB, Dille J, Rezende MC, Mei P, Almeida LH, Baldan $\mathrm{R}$, et al. Mechanical characterization of Ti-12Mo-13Nb alloy for biomedical Application hot swaged and aged. Materials Research. 2015;18(Supp1 2):8-12.

26. Kim HY, Ikehara Y, Kim JI, Hosoda H, Miyazaki S. Martensitic transformation, shape memory effect and superelasticity of Ti-Nb binary alloys. Acta Materials. 2006;54(9):2419-2429.

27. Nnamchi PS, Obayi CS, Todd I, Rainforth MW. Mechanical and eletromechanical characterization of new Ti-Mo-Nb-Zr alloys for biomedical applications. Journal of the Mechanical Behavior of Biomedical Materials. 2016;60:68-77.

28. Dercza G, Matula I, Zubkoa M, Kazek-Kesikb A, Maszybrockaa $\mathrm{J}$, Simkab W, et al. Synthesis of porous Ti-50Ta alloy by powder metallurgy. Materials Characterization. 2018;142:124-136.

29. Nunes ARV, Borborema S, Nunes CA, Araújo LS, Baldan R, Meid P, et al. Microstructure and mechanical properties of Ti-12Mo- $8 \mathrm{Nb}$ alloy hot swaged and treated for orthopedic applications. Materials Research. 2017;20(Suppl 2):526-531. 